U.S DEPARTMENT OF THE INTERIOR

U.S. GEOLOGICAL SURVEY

\title{
Borehole Geophysical Data From Eastland Woolen Mill Superfund Site, Corinna, Maine, March 1999
}

Open-File Report 01-186

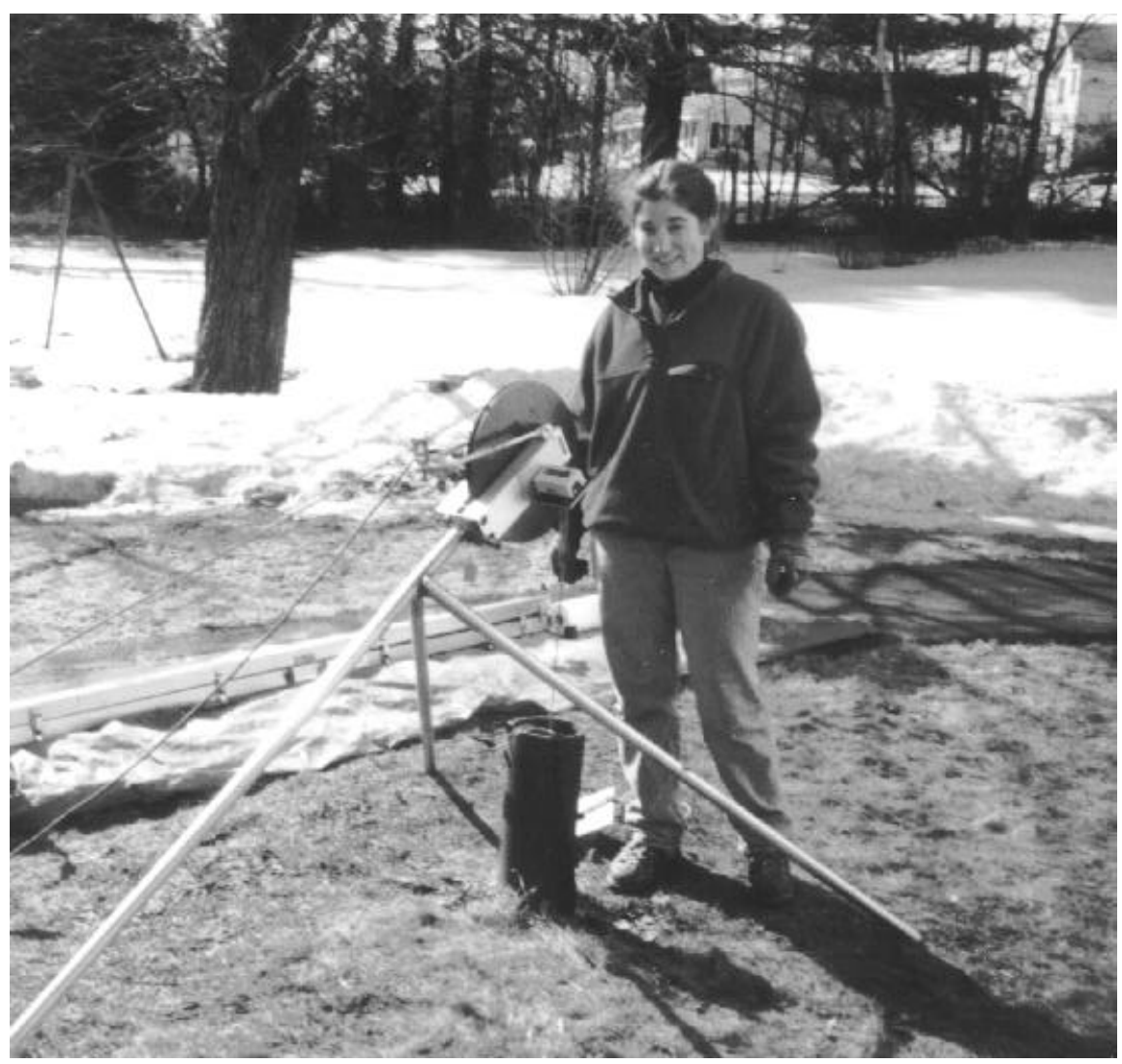

Prepared in cooperation with the

U.S. ENVIRONMENTAL PROTECTION AGENCY, REGION 1

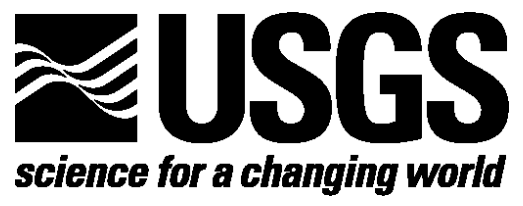


Cover Photograph. Joanna Wilson (1976-1999) performing geophysical logging of a well at the Eastland Woolen Mill Superfund site, March 1999. 


\section{Borehole Geophysical Data From Eastland Woolen Mill Superfund Site, Corinna, Maine, March 1999}

By Bruce P. Hansen, William J. Nichols, and Robert W. Dudley

U.S. GEOLOGICAL SURVEY

Open-File Report 01-186

Prepared in cooperation with the

U.S. ENVIRONMENTAL PROTECTION AGENCY, REGION 1

Augusta, Maine 2001 


\section{U.S. DEPARTMENT OF THE INTERIOR \\ GALE NORTON, Secretary}

U.S. GEOLOGICAL SURVEY

Charles G. Groat, Director

The use of firm, trade, and brand names in this report is for identification purposes

only and does not constitute endorsement by the U.S. Geological Survey.

For additional information write to:

Copies of this report can be purchased from:

District Chief

U.S. Geological Survey

26 Ganneston Drive

Augusta, ME 04330
U.S. Geological Survey

Information Services

Box 25286

Federal Center

Denver, CO 80225 


\section{CONTENTS}

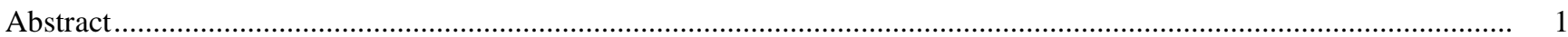

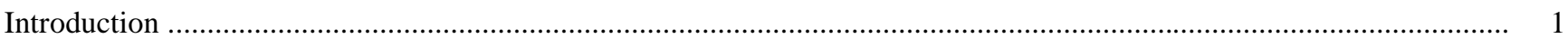

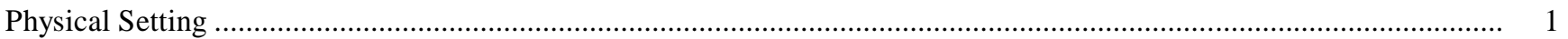

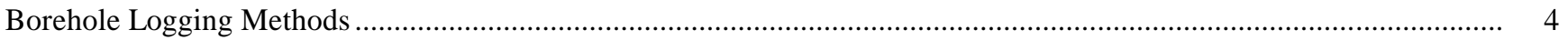

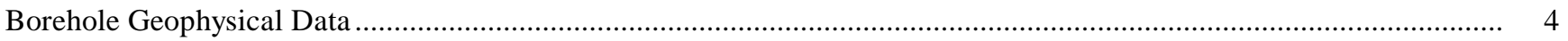

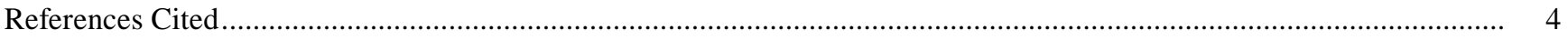

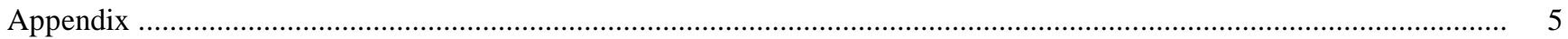

\section{FIGURES}

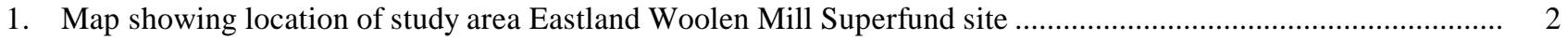

2. Map showing locations of logged bedrock wells at the Eastland Woolen Mill Superfund site ............................ 3

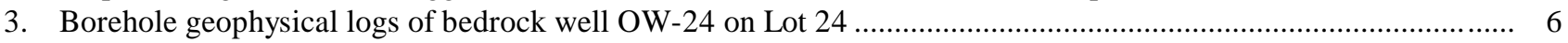

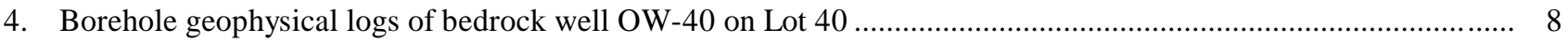

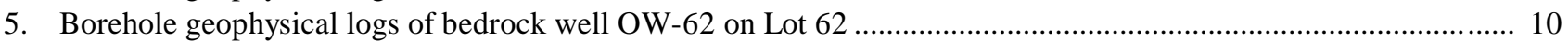

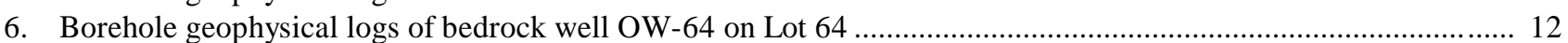

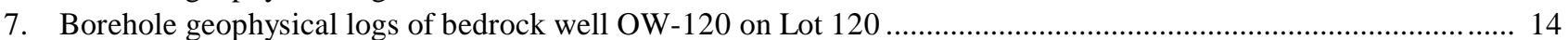

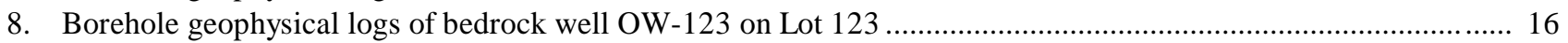

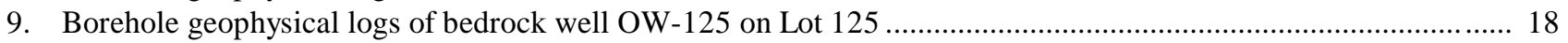

\section{TABLE}

1. Borehole geophysical data collection wells

\section{CONVERSION FACTORS}

\begin{tabular}{rll}
\hline Multiply & By & To obtain \\
\hline foot $(\mathrm{ft})$ & 0.3048 & meter \\
miles $(\mathrm{mi})$ & 1.609 & kilometers \\
ohm foot $(\mathrm{ohm} \mathrm{ft})$ & 1.609 & ohm meter \\
\hline
\end{tabular}

To convert temperature in degrees Fahrenheit $\left({ }^{\circ} \mathrm{F}\right)$ to degrees Celcius $\left({ }^{\circ} \mathrm{C}\right)$, use the following equation:

$$
{ }^{\circ} \mathrm{C}=5 / 9\left({ }^{\circ} \mathrm{F}-32\right)
$$

\section{ABBREVIATIONS}

degree $\left({ }^{\circ}\right)$ 


\title{
Borehole Geophysical Data From Eastland Woolen Mill Superfund Site, Corinna, Maine, March 1999
}

\author{
by Bruce P. Hansen, William J. Nichols, Jr., and Robert W. Dudley
}

\section{ABSTRACT}

Borehole-geophysical data were collected in cooperation with the U.S. Environmental Protection Agency in seven bedrock wells at the Eastland Woolen Mill Superfund site, Penobscot County, Corinna, Maine, in March, 1999. The data were collected as part of a reconnaissance investigation to provide information needed to address concerns about the distribution and fate of contaminants in ground-water at the site. The borehole geophysical data were also needed to guide subsequent data collection associated with the development of a remediation workplan. The borehole geophysical logs collected included: natural gamma, caliper, fluid temperature, fluid conductivity, electromagnetic conductivity, electromagnetic resistivity, spontaneous potential, and single-point resistivity.

\section{INTRODUCTION}

The Eastland Woolen Mill site, located in Corinna, Maine (fig. 1), has been designated by the U.S. Environmental Protection Agency (USEPA) as a Superfund site under the Comprehensive Environmental Response, Compensation, and Liability Act of 1980 (CERCLA). As a result of past manufacturing and disposal practices at the Eastland Woolen Mill, soil and groundwater beneath and adjacent to the site contain dissolved chlorobenzenes (Acheron, 1994). The area contaminated with chlorobenzenes is extensive and, at present (1999), not well defined (Harding Lawson Associates, 1999).

In order to provide some of the required information to guide development of a work plan for a Remedial Investigation (RI) at the site, the U.S. Geological Survey (USGS), in cooperation with the USEPA, con- ducted a reconnaissance investigation collecting geologic, water level, and borehole geophysical data to describe the geohydrology and ground-water flow system of the site. The borehole geophysical logs were collected to supplement surface geologic information and provide sub-surface information on bedrock lithology, structure, and water-yielding fracture zones.

This report presents borehole-geophysical data that were collected in seven bedrock wells from March 1, 1999 to March 11, 1999. Surface-water and groundwater-level data that have been collected in the study area are presented in a separate data report.

\section{PHYSICAL SETTING}

The study area includes the Eastland Woolen Mill Superfund site and adjacent areas. The study area is adjacent to the East Branch Sebasticook River just downstream of Corundel Lake. The former Eastland Woolen Mill complex straddles the river (fig. 2).

The location of wells where borehole-geophysical data were collected are shown on figure 2 and are identified by project identification numbers which correspond to property lot locations. For example, well OW-24 is located on property Lot 24 . Each well also has a local USGS 15-digit site number based on the latitude and longitude grid system. The first six digits denote degrees, minutes, and seconds of lattitude; the next seven digits denote degrees, minutes, and seconds of longitude. The last two digits, assigned sequentially, uniquely differentiate all wells that fall within a 1-second grid. These latitude-longitude identification numbers are the primary identifiers in the USGS groundwater site inventory (GWSI) data base. The identifying numbers for each site are shown in table 1. 


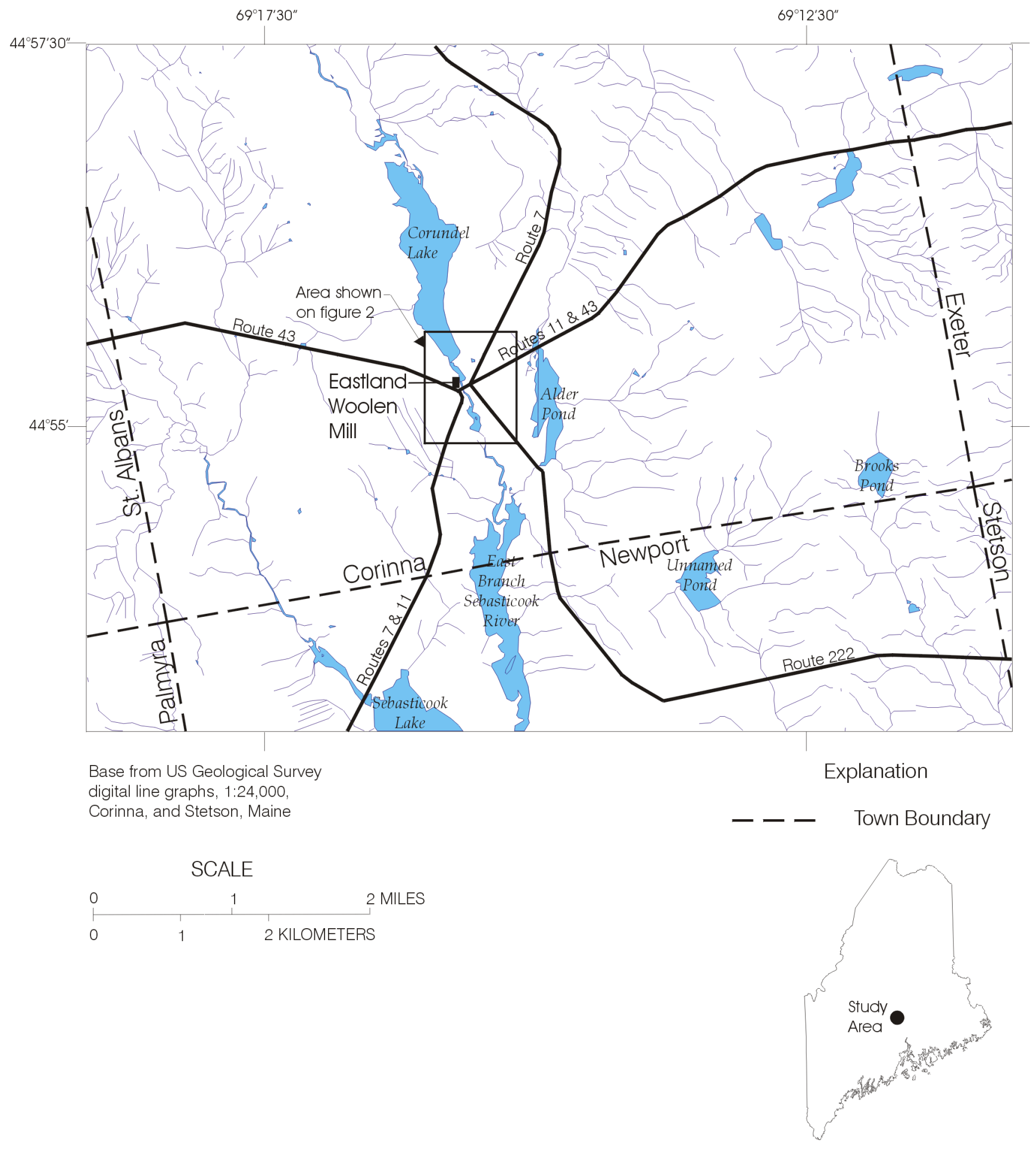

Figure 1. Location of study area Eastland Woolen Mill Superfund site, Corinna, Maine. 


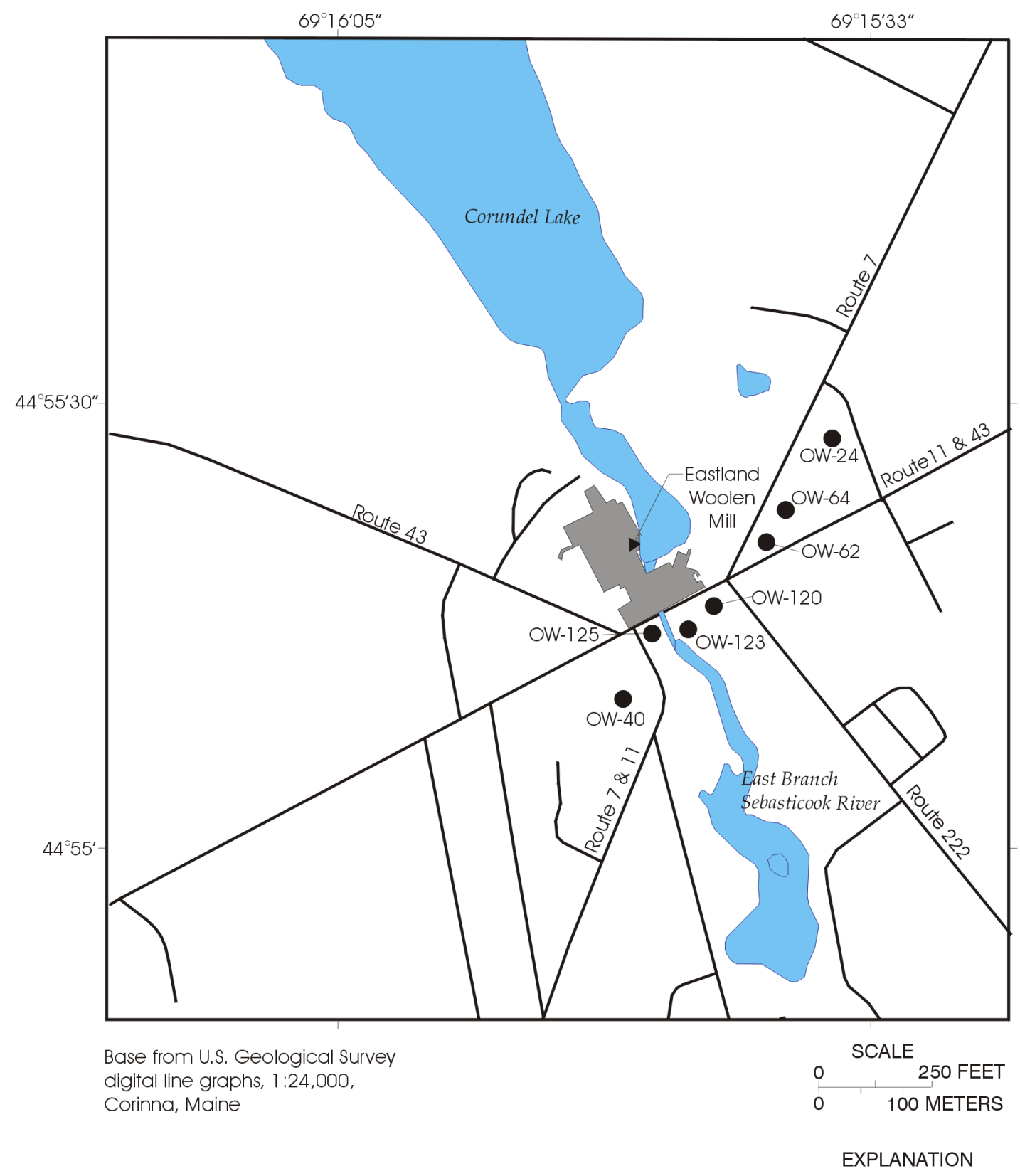

OW-40 WELL AND IDENTIFICATION NUMBER

Figure 2. Locations of logged bedrock wells at the Eastland Woolen Mill Superfund site, Corinna, Maine. 
The authors thank Carole Johnson and Joanna Wilson (USGS) who collected geophysical log data, Ed Hathaway, Project Manager, USEPA, for facilitating access to data-collection sites, and Scott Calkin (Harding Lawson Associates) who provided on-site logistical support.

Table 1. Borehole geophysical data collection wells.

\begin{tabular}{|c|c|c|}
\hline Project Identifier & USGS Identifier & $\begin{array}{l}\text { Latitude } \\
\text { Longitude }\end{array}$ \\
\hline OW-24 & 445524069152701 & $\begin{array}{r}44^{\circ} 55^{\prime} 24 \\
069^{\circ} 15^{\prime}\end{array}$ \\
\hline OW-40 & 441512069154101 & $\begin{array}{r}44^{\circ} 15^{\prime} " 12^{\prime} \\
069^{\circ} 15^{\prime}\end{array}$ \\
\hline OW-62 & 445510069153201 & $\begin{array}{r}44^{\circ} 55^{\prime \prime} 10^{\prime} \\
069^{\circ} 15^{\prime} 32\end{array}$ \\
\hline OW-64 & 445521069153201 & $\begin{array}{r}44^{\circ} 55^{\prime}, 21^{\prime} \\
069^{\circ} 15^{\prime} " 32^{\prime}\end{array}$ \\
\hline OW-120 & 445516069153701 & $\begin{array}{r}44^{\mathrm{o}} 55^{\prime \prime} 16^{\prime} \\
069^{\circ} 15^{\prime} " 37^{\prime}\end{array}$ \\
\hline OW-123 & 445515069153801 & $\begin{array}{r}44^{\circ} 55^{\prime \prime} 15^{\prime} \\
069^{\circ} 15^{\prime} 38\end{array}$ \\
\hline OW-125 & 445515069153901 & $\begin{array}{r}44^{\mathrm{O}} 55^{\prime \prime} 15^{\prime} \\
069^{\circ} 15^{\prime}, 39^{\prime}\end{array}$ \\
\hline
\end{tabular}

\section{BOREHOLE LOGGING METHODS}

Borehole geophysical logs were collected in seven bedrock wells during this study to supplement sub-surface geologic information obtained to identify potential water-yielding fractures or fracture zones. Borehole geophysical logs presented in this report include: natural gamma, fluid temperature, fluid conductivity, electromagnetic conductivity, electromag- netic resistivity, spontaneous potential, and singlepoint resistivity. The logs were collected using a single-conductor logging system that recorded digital data from each $0.1 \mathrm{ft}$ interval. The suite of conventional logs used for this investigation are described in detail in a number of readily available references (such as Keys, 1990 and Cohen, 1995) and will not be described here.

\section{BOREHOLE GEOPHYSICAL DATA}

The borehole geophyscial logs for each of the seven bedrock wells investigated are shown in figures 3-9 in the appendix of this report. The digital data of the geophysical logs presented in this report are on file at the USGS office in Augusta, Maine.

\section{REFERENCES CITED}

Acheron, Inc., 1994, Proposed ground-water pumping plan for downtown Corinna, Maine: Winthrop, Maine, 25 p.

Cohen, Andrew J.B., 1995, Hydrogeologic characterization of fractured rock formations: A guide for groundwater remediators: Berkeley, CA, Ernest Orlando Lawrence Berkeley National Laboratory, LBL-38142/UC-800, $144 \mathrm{p}$.

Harding Lawson Associates, 1999, Preliminary RI workplan for Eastland Woolen Mill site Corinna, Maine: Portland, Maine, $5 \mathrm{p}$.

Keys, W.S., 1990, Borehole geophysics applied to groundwater investigations: U.S. Geological Survey Techniques of Water-Resources Investigations, book 2, chap. E2, 150 p.U.S. Department of Commerce, National Oceanic and Atmospheric Administration, 1996, Climatological data, annual summary, New England, v. 108, no. 13, 35 p. 


\section{APPENDIX}

Figures 3-9: Borehole Geophysical Logs 

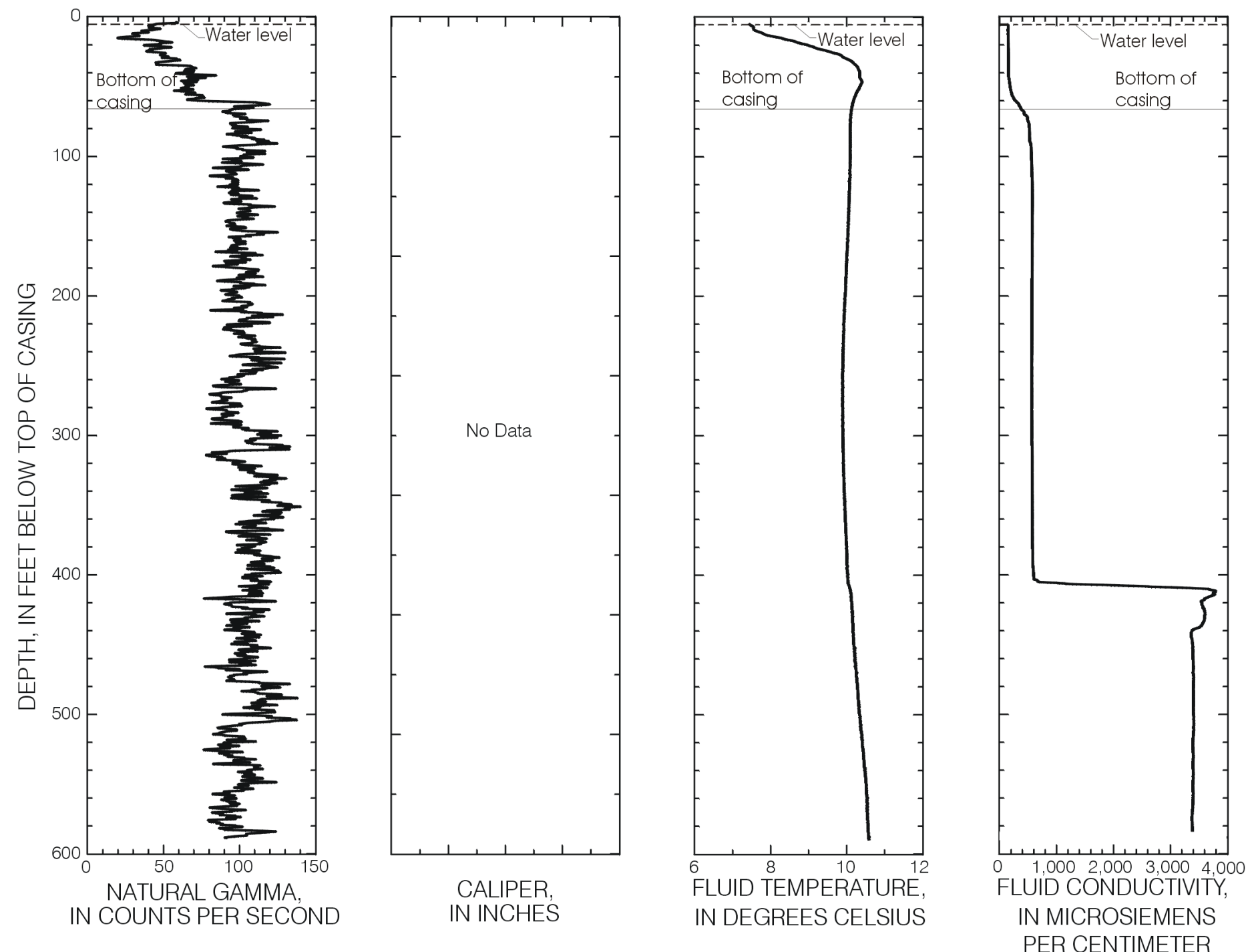

Figure 3. Borehole geophysical logs of bedrock well OW-24 on Lot 24 in Corinna, Maine 

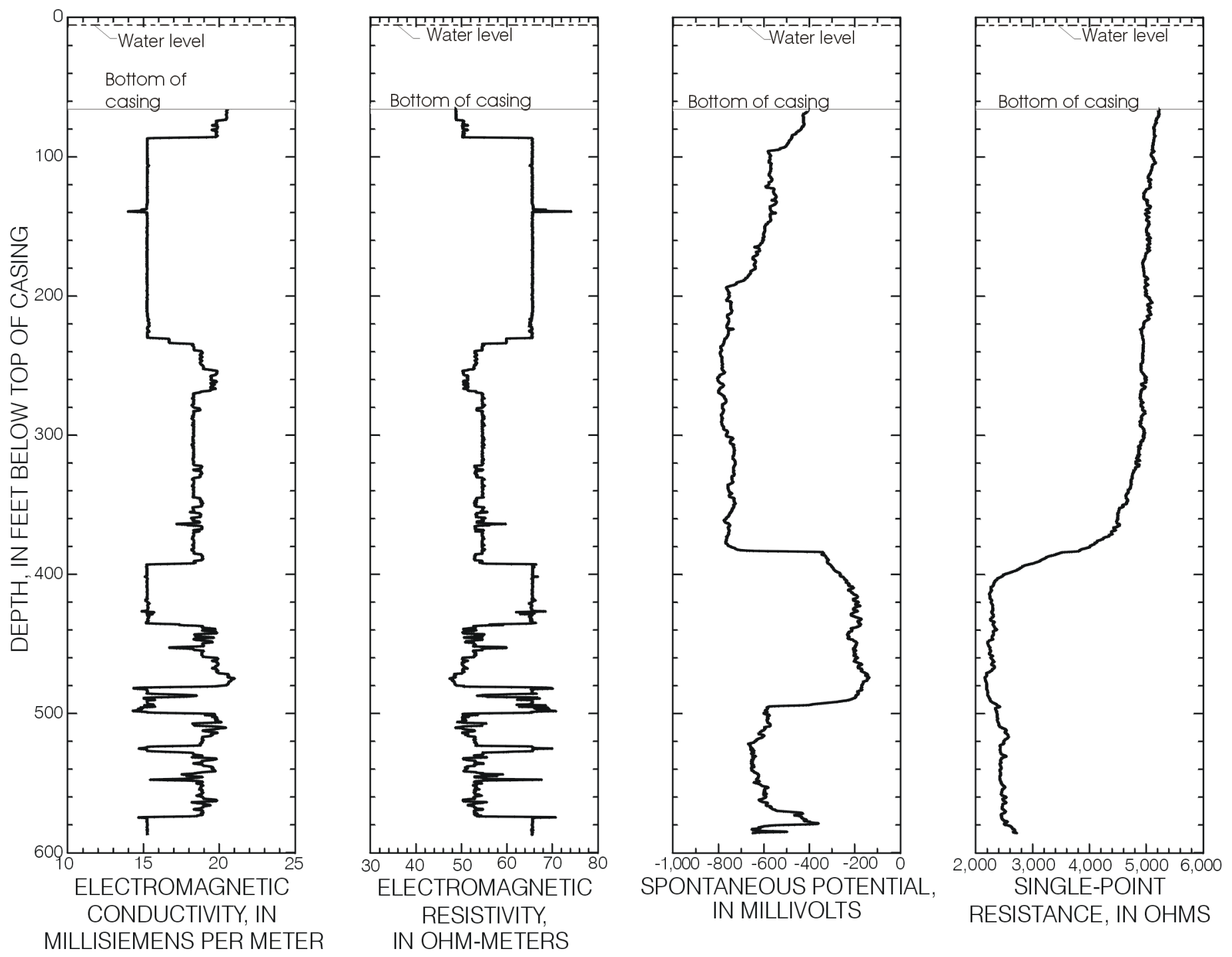

IN OHM-METERS

Figure 3. Borehole geophysical logs of bedrock well OW-24 on Lot 24 in Corinna, Maine - Continued. 

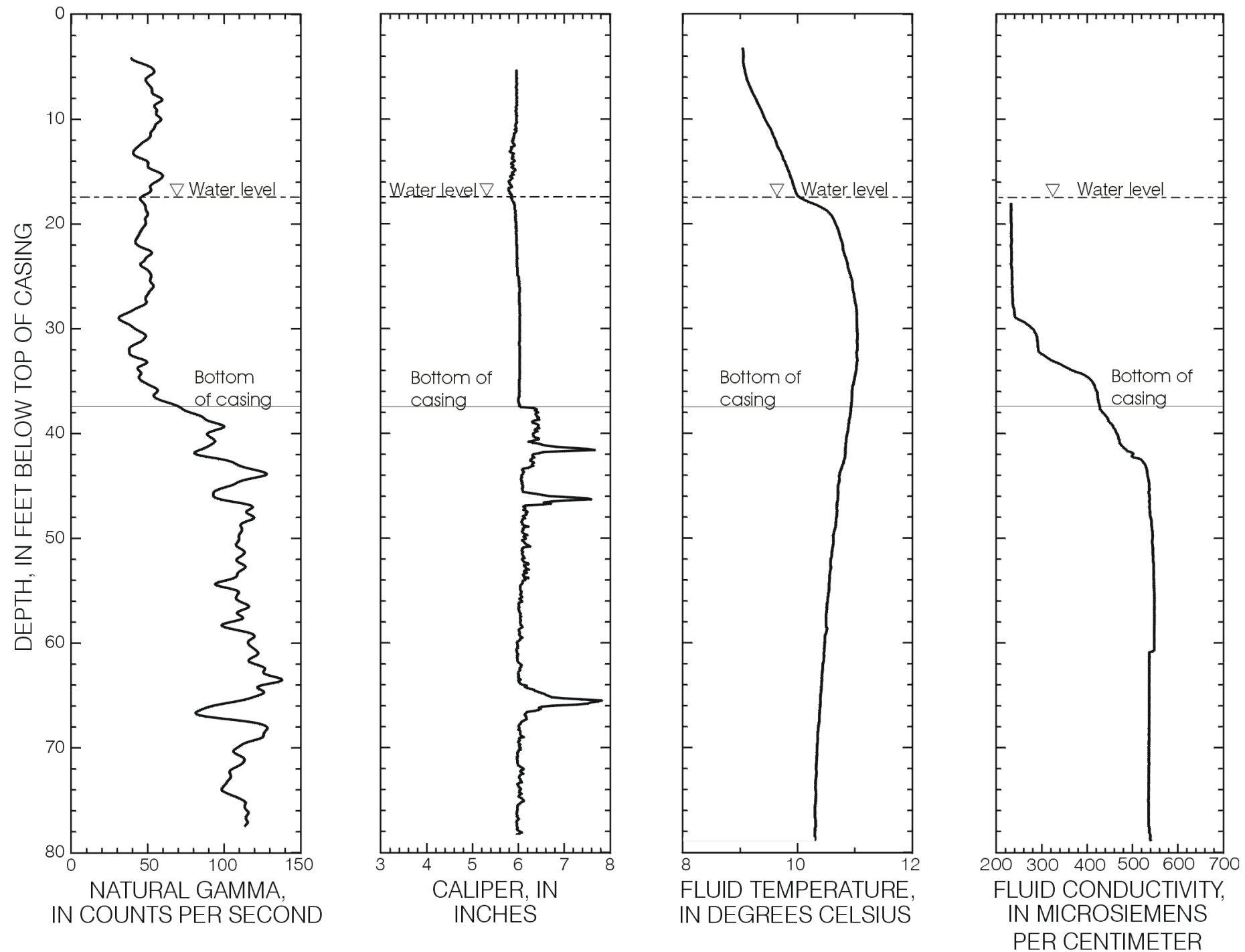

Figure 4. Borehole geophysical logs of bedrock well OW-40 on Lot 40 in Corinna, Maine 



Figure 4. Borehole geophysical logs of bedrock well OW-40 on Lot 40 in Corinna, Maine - Continued. 

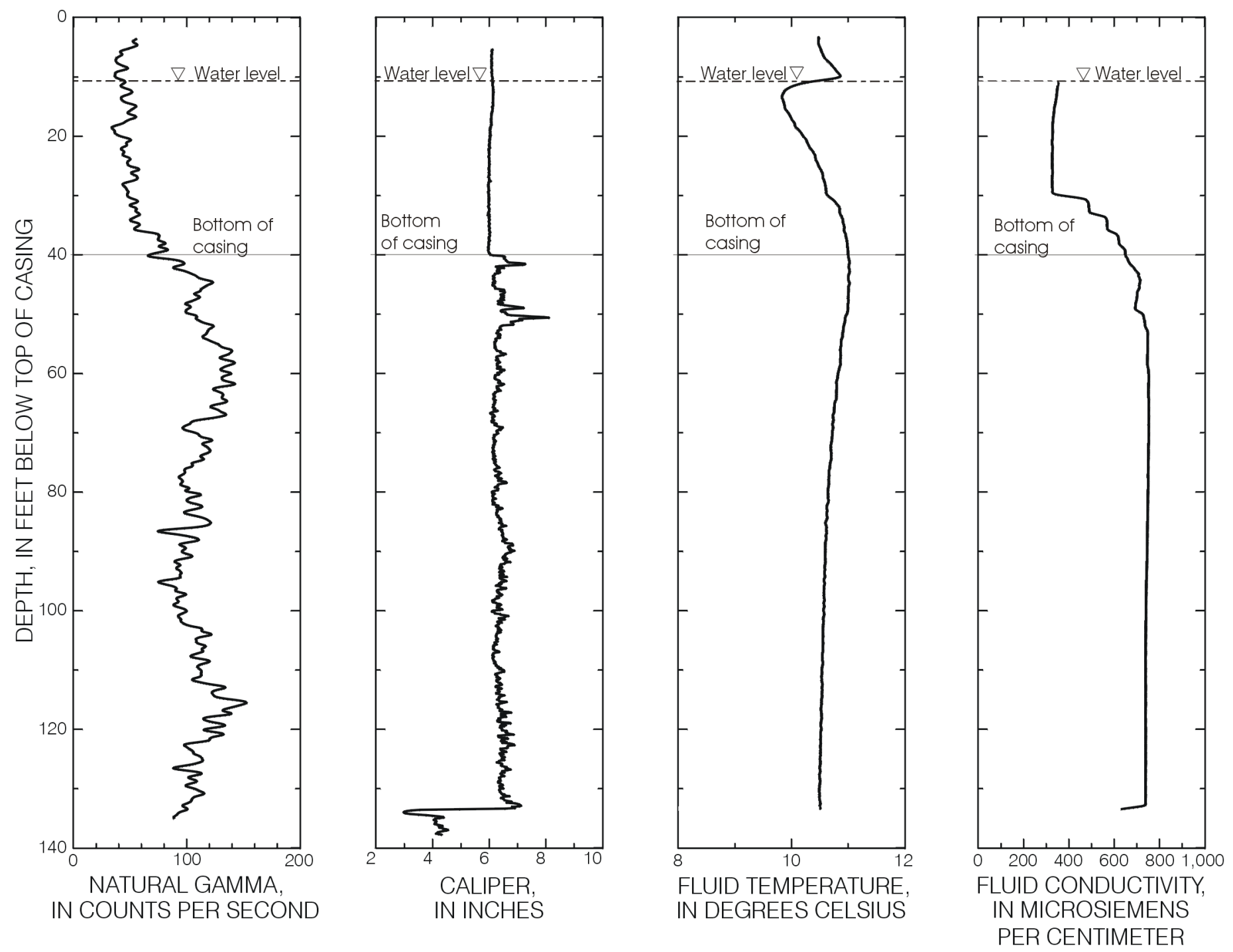

Figure 5. Borehole geophysical logs of bedrock well OW-62 on Lot 62 in Corinna, Maine 

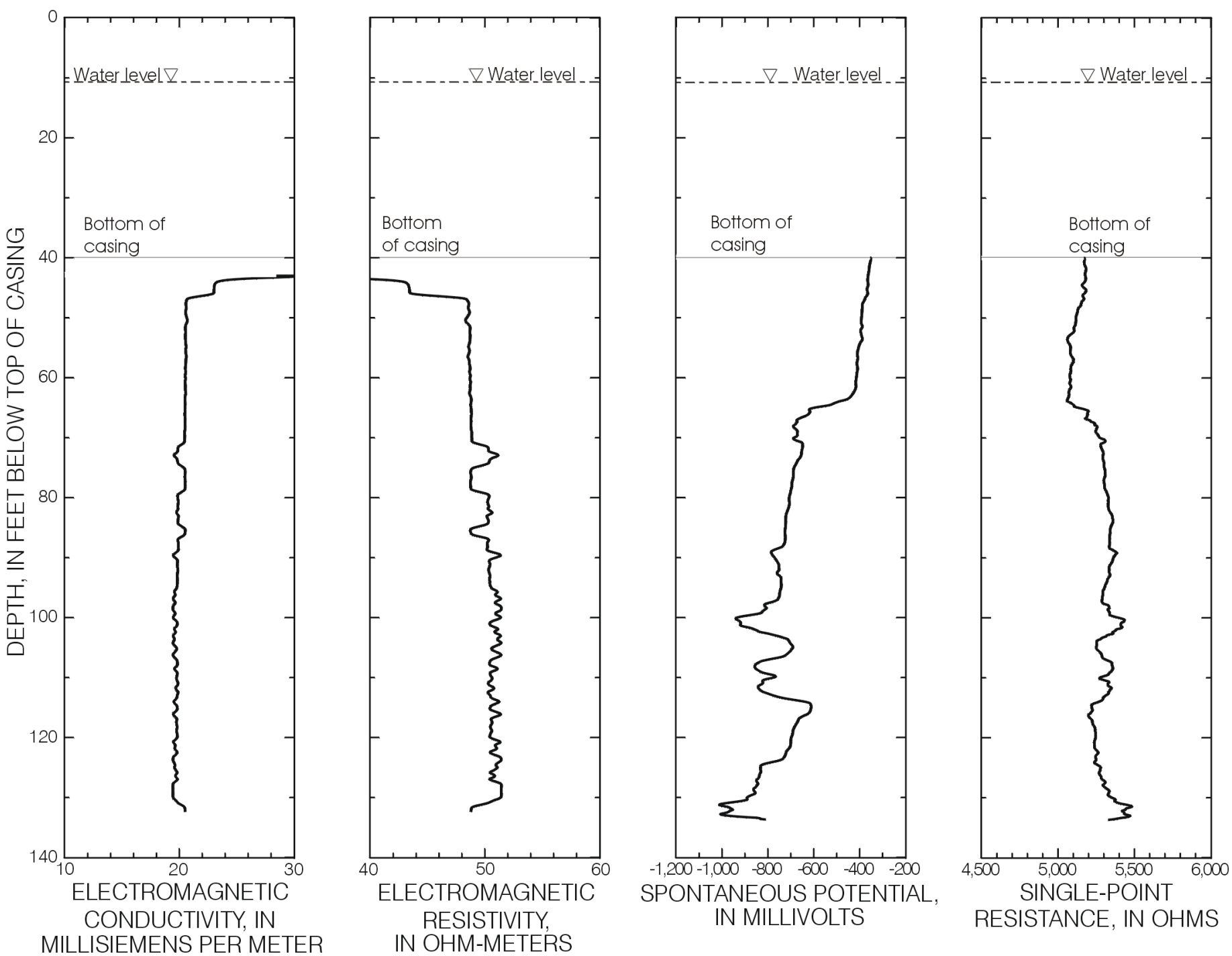

Figure 5. Borehole geophysical logs of bedrock well OW-62 on Lot 62 in Corinna, Maine - Continued. 

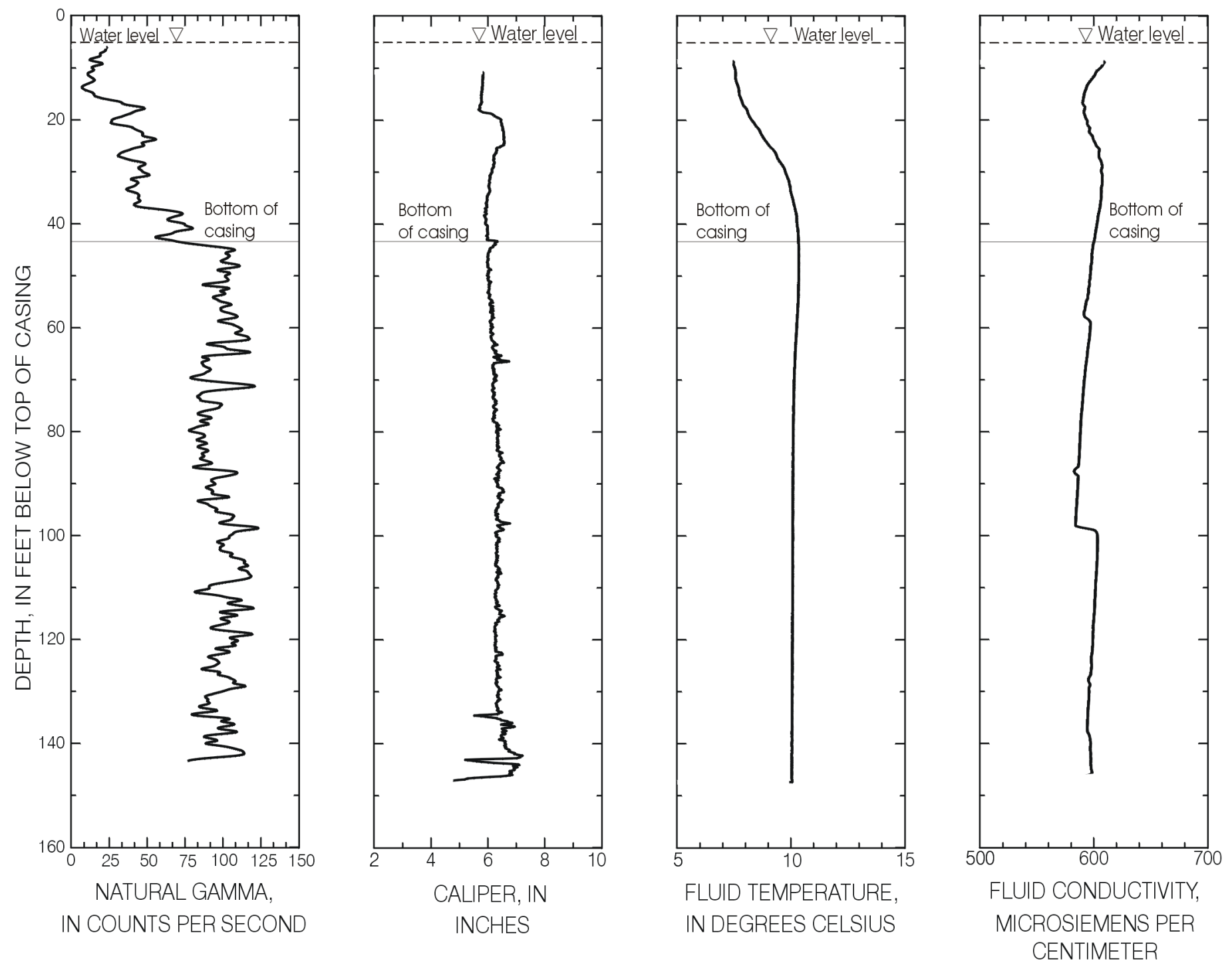

Figure 6. Borehole geophysical logs of bedrock well OW-64 on Lot 64 in Corinna, Maine 



Figure 6. Borehole geophysical logs of bedrock well OW-64 on Lot 64 in Corinna, Maine - Continued. 

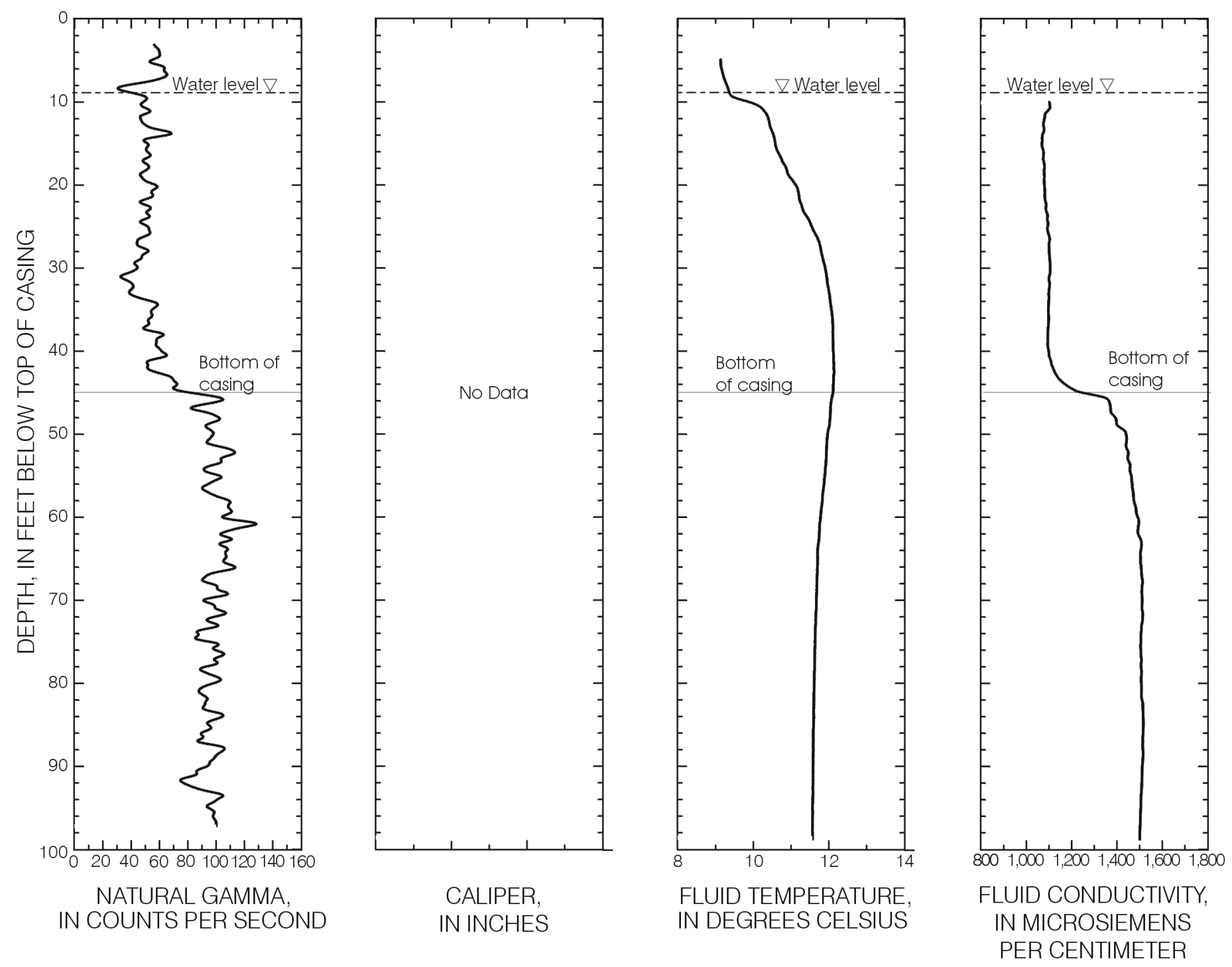

Figure 7. Borehole geophysical logs of bedrock well OW-120 on Lot 120 in Corinna, Maine 

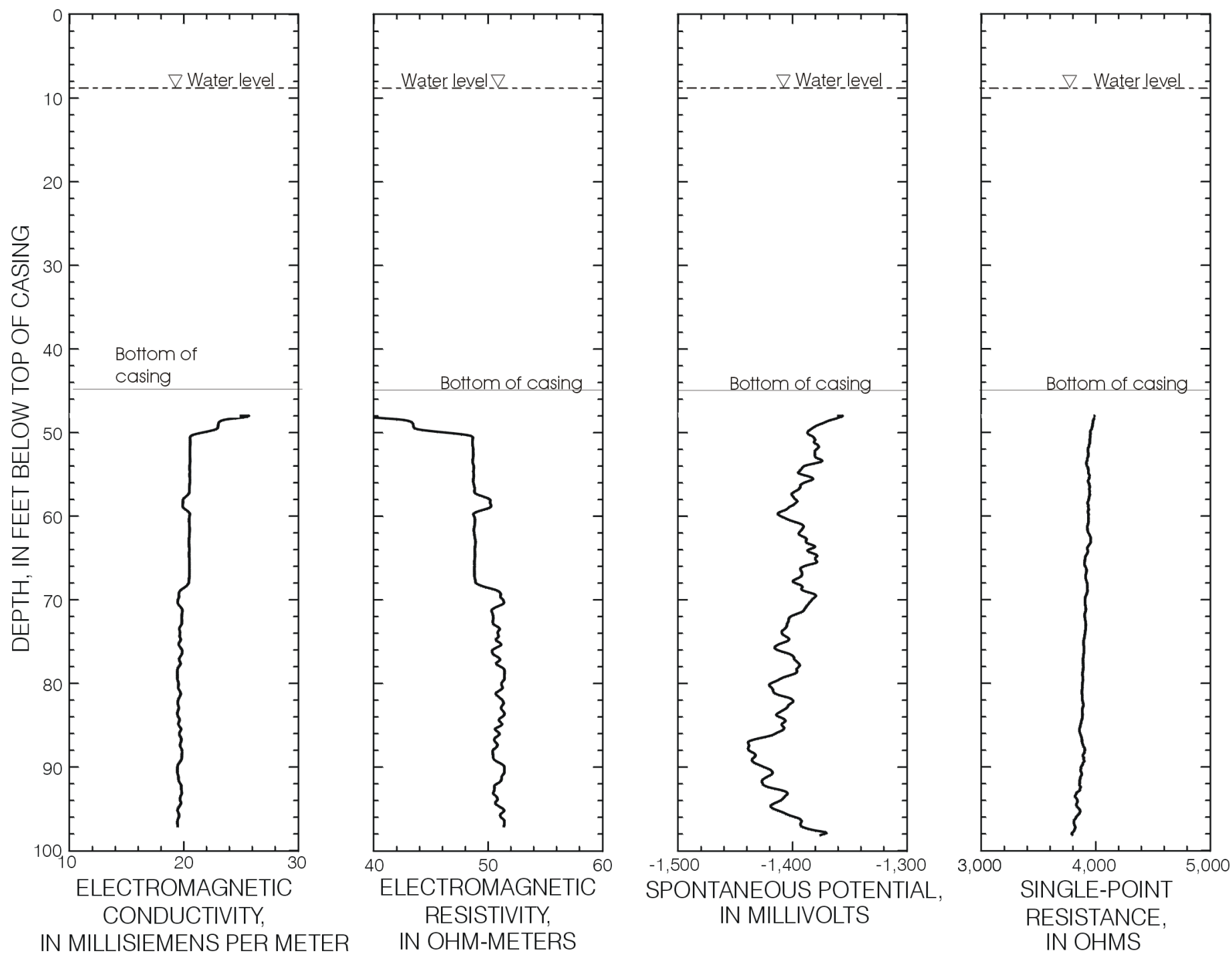

Figure 7. Borehole geophysical logs of bedrock well OW-120 on Lot 120 in Corinna, Maine - Continued 

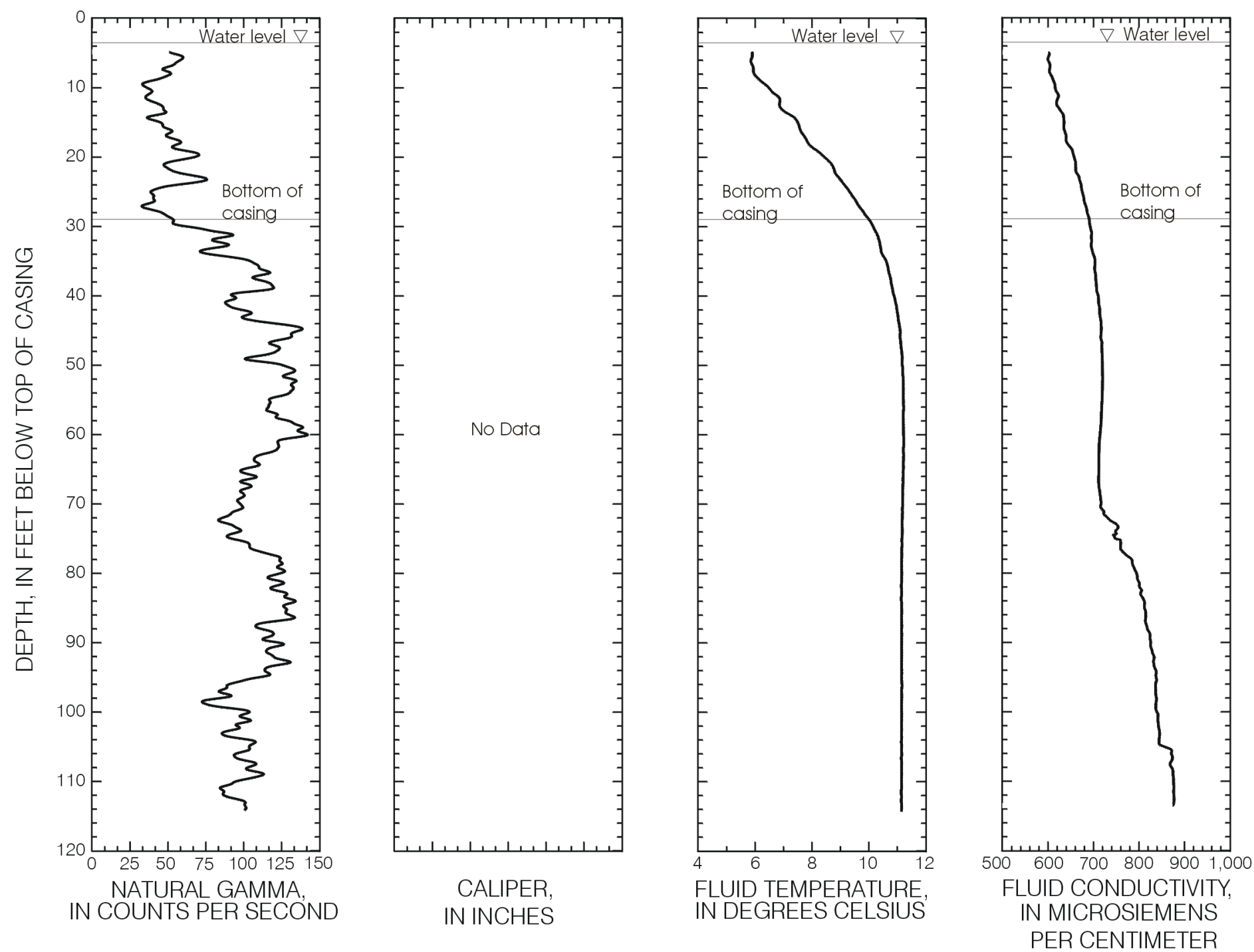

Figure 8. Borehole geophysical logs of bedrock well OW-123 on Lot 123 in Corinna, Maine 

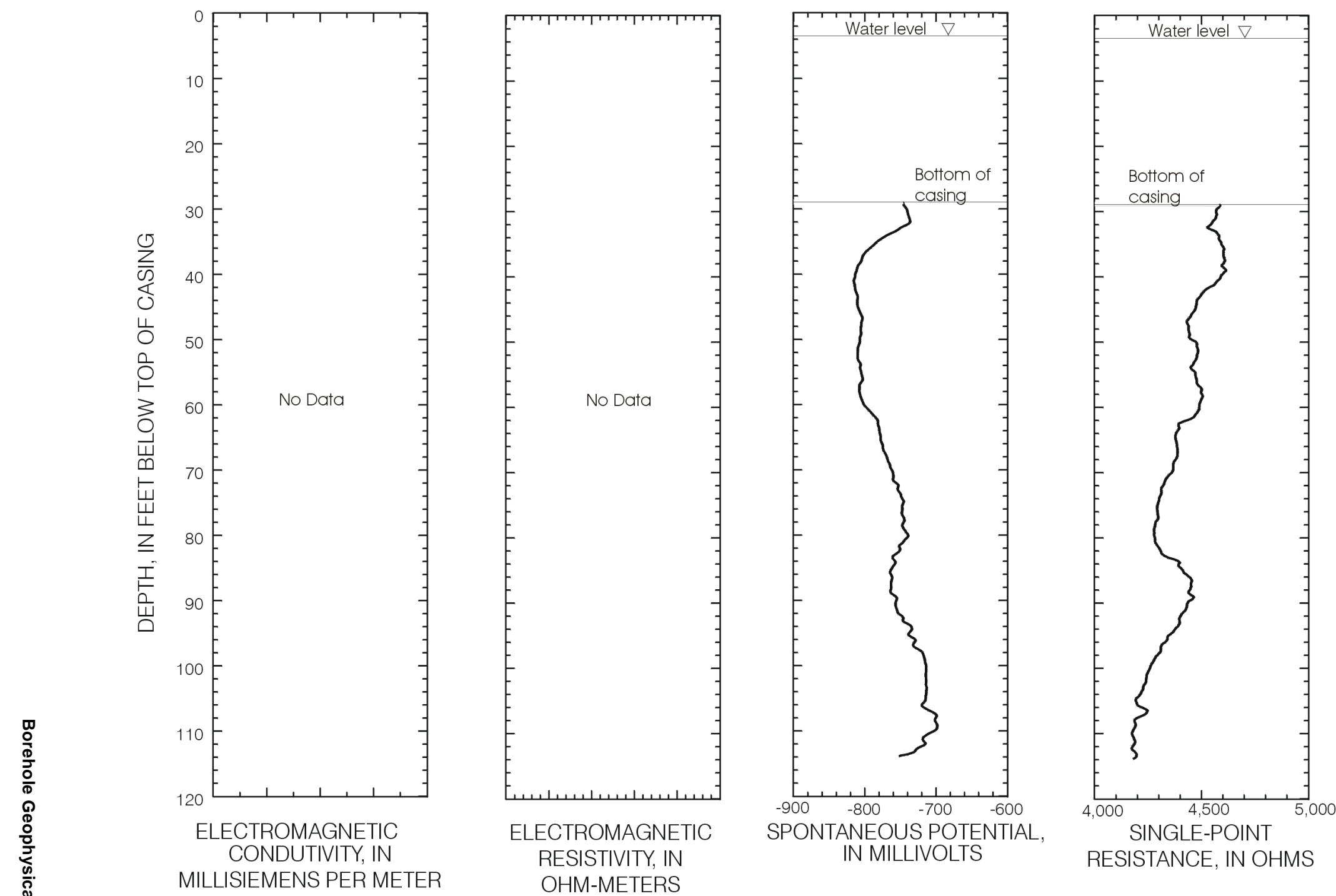

Figure 8. Borehole geophysical logs of bedrock well OW-123 on Lot 123 in Corinna, Maine - Continued. 

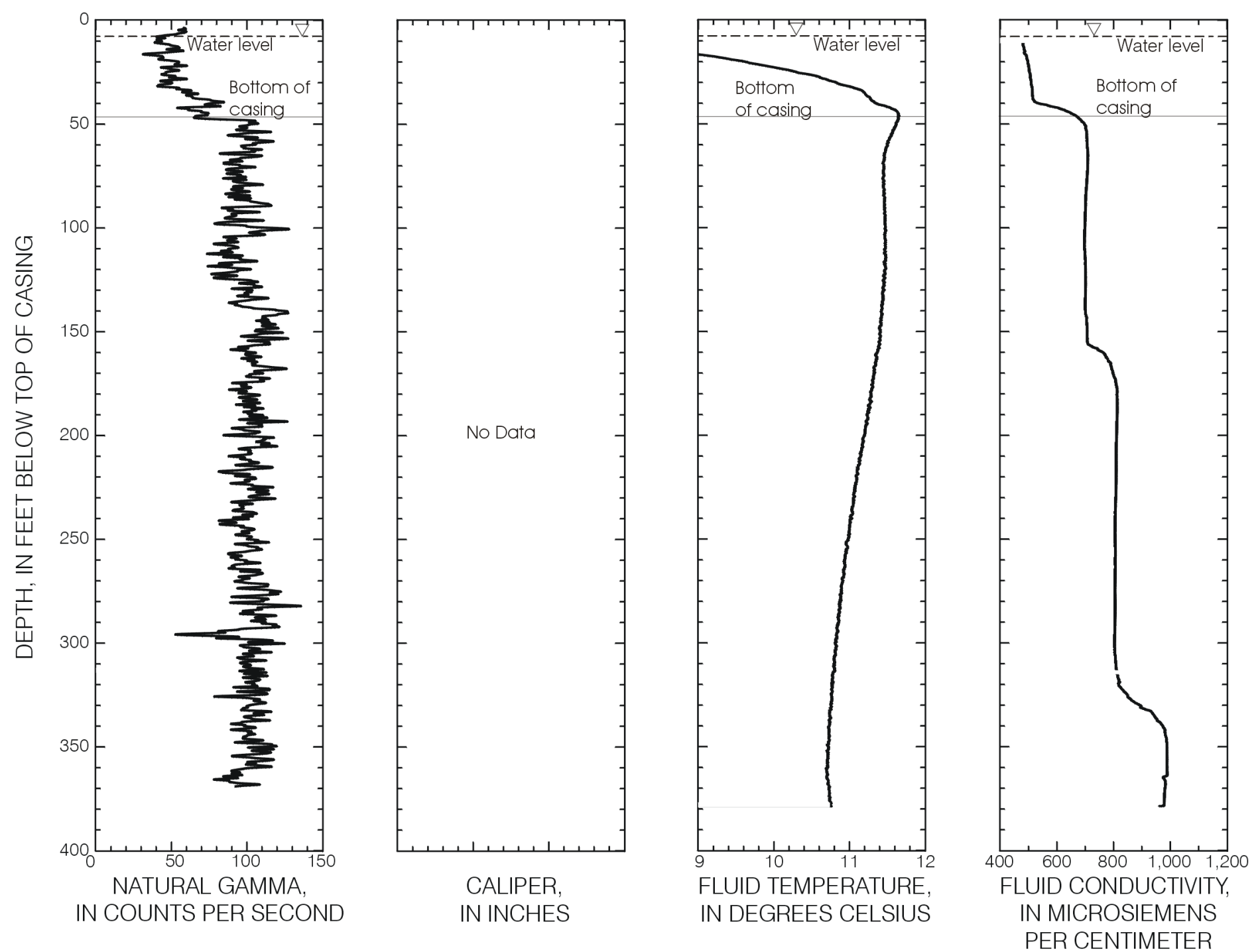

Figure 9. Borehole geophysical logs of bedrock well OW-125 on Lot 125 in Corinna, Maine 

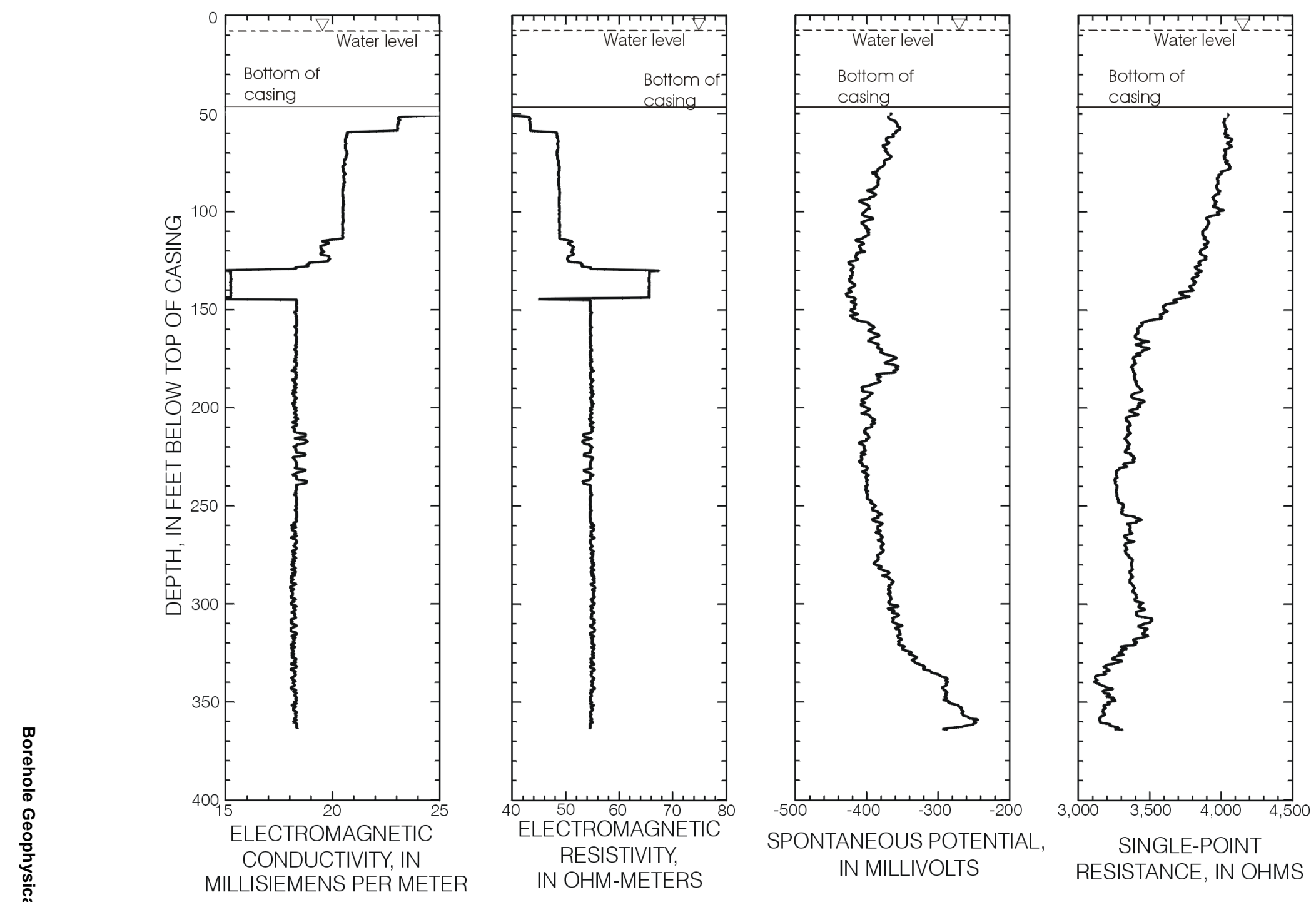

Figure 9. Borehole geophysical logs of bedrock well OW-125 on Lot 125 in Corinna, Maine - Continued. 
District Chief

Maine District

U.S. Geological Survey

Water Resources Division

26 Ganneston Drive

Augusta, ME 04330 